\title{
Monitoring late-successional forest biodiversity in the Pacific Northwest, U.S.A.
}

\author{
by Thomas A. Spies ${ }^{1}$ and Jon R. Martin²
}

\begin{abstract}
The era of ecosystem management for federal forest lands in the Pacific Northwest began in 1994 with the adoption of the Northwest Forest Plan. This plan was designed to maintain and restore species and ecosystems associated with late successional and old-growth forests on over 10 million ha of federal lands in Washington, Oregon and California. The plan called for implementation monitoring, effectiveness monitoring, and validation monitoring for a variety of ecological and socio-economic components. Monitoring has become a central part of management of the federal forests in the region and managers and scientists have gained considerable experience in implementing this large and complex program. The components of the monitoring plan include late-successional/old growth vegetation, northern spotted owls, marbled murrelets, aquatic habitat and social conditions. The monitoring plan is strongly based on vegetation layer created with TM satellite imagery and on a regional grid of forest inventory plots. The lessons learned from the implementation of this monitoring plan include: 1) agencies need to devote considerable resources to insure that effective monitoring will occur at broad scales; 2) aggregation of local monitoring efforts is not a substitute for a designed regional monitoring plan; 3 ) vegetation structure and composition, measured with satellite imagery and inventory plots, is a costeffective, broad-scale indicator of biological diversity; 4) some species, such as threatened and endangered species, are not necessarily covered with habitat approaches and may require population monitoring; 5) our scientific understanding of monitoring components will vary widely as will the approaches to data collection and analysis; 6) monitoring requires research support to develop and test metrics and biodiversity models; 7 ) links of monitoring to decision-making (adaptive management) are still being forged.
\end{abstract}

Key words: aquatic ecosystems, endangered species, old-growth forests, Pacific Northwest, USA, regional ecosystem management

\section{RÉSUMÉ}

L'histoire de l'aménagement écosystémique des terres forestières fédérales du Nord-Ouest du Pacifique a débuté en 1994 par l'adoption du Plan forestier du Nord-Ouest. Ce plan a été conçu pour préserver et restaurer les espèces et les écosystèmes associés aux forêts de fin de succession et aux vieilles forêts réparties sur plus de 10 millions d'ha de terres fédérales retrouvées dans l'État de Washington, de l'Oregon et de la Californie. Le plan faisait appel au suivi de l'implantation, au suivi de l'efficacité et au suivi de la validation de plusieurs composantes écologiques et socioéconomiques. Le suivi est devenu le principal élément de l'aménagement des forêts des terres fédérales de la région et les aménagistes ainsi que les chercheurs ont acquis beaucoup d'expérience au cours de l'implantation de ce programme étendu et complexe. Les composantes du plan de suivi portent sur la végétation de fin de succession/vieilles forêts, la chouette tachetée, l'alque marbrée et l'état des habitats aquatiques et sociaux. Le plan de suivi repose beaucoup sur les étages de végétation créés par l'imagerie de télédétection et le quadrillage régional des parcelles d'inventaire forestier. Les leçons tirées de l'implantation du plan de suivi sont : 1) les agences doivent consacrer d'importantes ressources pour s'assurer qu'un suivi efficace sera effectué à grande échelle; 2) l'agrégation d'efforts locaux de suivi n'est pas un substitut à un plan de suivi conçu à l'échelle régionale; 3) la structure et la composition de la végétation, mesurées à partir de l'imagerie de télédétection et des parcelles d'inventaire, constituent un indicateur général rentable de la diversité biologique; 4) certaines espèces, comme les espèces menacées ou en péril, ne sont nécessairement couvertes par les approches en fonction de l'habitat et pourraient nécessité un suivi des populations; 5) notre compréhension scientifique des éléments de suivi varie grandement en fonction du développement des approches de collecte et d'analyse des données; 6) le suivi nécessite l'aide de la recherche pour élaborer et tester des modèles de mesures et de biodiversité; 7) des liens entre le suivi et la prise de décision (aménagement adaptatif) doivent être élaborés.

Mots clés : écosystèmes aquatiques, espèces menacées, vieilles forêts, Nord-Ouest du Pacifique, É.-U., aménagement écosystémique régional

\footnotetext{
${ }^{1}$ USDA Forest Service, Pacific Northwest Research Station, 3200 Jefferson Way, Corvallis, Oregon 97331. E-mail: tspies@fs.fed.us
}

${ }^{2}$ USDA Forest Service, Region 6, Portland, Oregon. 97204. E-mail: jrmartin@fs.fed.us 


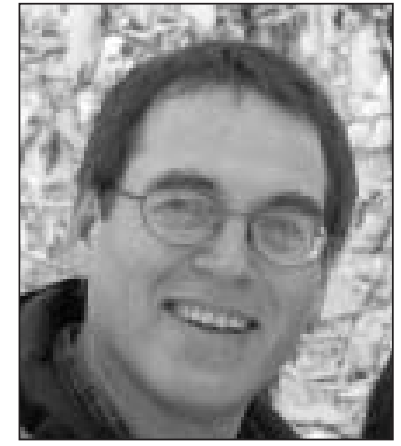

Thomas A. Spies

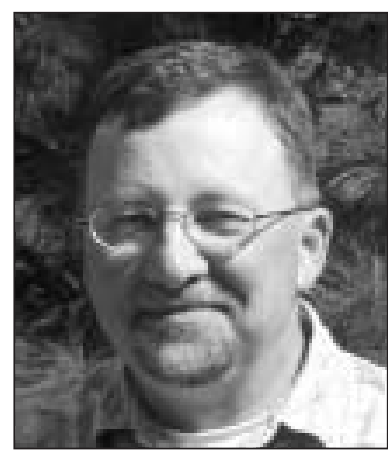

Jon R. Martin

\section{Introduction}

The era of ecosystem management on federal forest lands in the Pacific Northwest and northern California began in 1994 with the adoption of the Northwest Forest Plan (NWFP) (FEMAT 1993). This plan was the first comprehensive regional forest ecosystem plan in the world designed to maintain and restore species and ecosystems associated with late successional and old-growth forests and aquatic ecosystems. Covering over 10 million ha of federal lands, the goal of the plan was set by then President Clinton who asked a team of scientists to develop alternatives that "would attain the greatest economic and social contributions from the forest and also meet the requirements of applicable [environmental] laws and regulations." The alternatives had to meet the following objectives: 1) maintenance and/or restoration of habitat conditions for the northern spotted owl and marbled murrelets that will provide for viability of each species; 2) maintenance and/or restoration of habitat conditions to support viable populations of species known to be associated with old-growth forest conditions; 3) maintenance and/or restoration of spawning and rearing habitat on federal lands to support recovery and maintenance of viable populations of anadromous fish species; 4) maintenance and/or creation of a connected or interactive old-growth forest ecosystem on federal lands.

The scientists developed nine alternatives and the President selected one, option 9, which was almost immediately challenged by lawsuits from both timber and environmental interests. The lawsuits were not successful and one year later, a federal judge found that the NWFP was in compliance with environmental laws but he also warned that "monitoring is central to the [NWFP] validity. If it is not funded, or done for any reason, the plan will have to be reconsidered." Thus began one of the largest regional forest monitoring programs ever attempted.

The plan has been in place for about 10 years now and federal managers and scientists have developed and implemented a comprehensive monitoring strategy that is one of the most comprehensive and largest for any region in the world (Mulder et al. 1999). The total budget for the monitoring program in federal fiscal year 2003 was over 6 million dollars. We will review the main components of the plan and discuss some of the lessons learned from the effort to implement the monitoring component.

\section{Components of the Plan}

The plan contained three major types of monitoring: (1) implementation - were the standards and guidelines followed?; (2) effectiveness - did the management actions achieve the desired goals?; and (3) validation - are the underlying management and scientific assumptions correct? These three types of monitoring were applied to five components: (1) old-growth ecosystems; (2) the northern spotted owl (Strix occidentalis caurina); (3) marbled murrelet (Brachyrampus marmoratus); (4) aquatic ecosystems; (5) socio-economic benefits; and (6) tribal relations. Thus, the monitoring plan contained both focal species components and whole ecosystems components, as well as human dimensions. A critical step in the monitoring process was to clearly identify expectations under the original plan and use these to form questions that focus the collection and analysis of data. Coordinated programs were developed for both implementation monitoring and effectiveness monitoring. Validation monitoring, which was seen as largely a research effort by managers and policy makers, was not formally developed into a program. This paper will focus on the major components of the effectiveness monitoring program and identify some of the lessons learned from monitoring in the first decade.

\section{Late-successional and old-growth monitoring}

The central component of the monitoring plan is the measurement of status and trends in late successional (mature and old-growth) and old-growth forests in the region (Hemstrom et al. 1998). These forests are defined ecologically based on a variety of structural and compositional elements. For Douglas-fir (Pseudotsuga menziesii) forests, mature forest conditions begin around 80 years of age, although there is considerable variation in structure among stands with similar ages. Old-growth forest structures can be found in Douglasfir stands 150 to over 800 years in age (Franklin et al. 2002).

These forests are monitored using two methods: (1) spatial models developed by the Interagency Vegetation Mapping Project (IVMP) using satellite imagery and GIS, and (2) a grid of inventory plots spaced every $5.4 \mathrm{~km}$ on public and private lands. These two different methods are complementary. The spatial vegetation models are used to estimate spatial distribution and pattern based on predictive models of canopy cover, composition (conifer vs. hardwood), quadratic mean diameter (QMD) of the upper canopy, and canopy heterogeneity (Cohen et al. 2001). The inventory plots are used to provide an estimate of area of forest structure and composition with a known degree of statistical reliability. They are also used to estimate characteristics of forests that cannot be measured with satellite imagery, such as dead wood and understory structure and composition. The spatial monitoring is intended to be repeated on a five- to 10-year interval and the inventory grid re-measured on a 10-year cycle with a subset measured every year.

Both the spatial and plot-based measurements provide continuous estimate of old-forest characteristics. Consequently, it is possible to use different definitions of older forest, a valuable feature since the definition of old growth varies by environment, forest type, and interest group. The flexible vegetation layers also make it possible to develop custom habitat models for other late-successional species 
whose habitat is not well defined by a standard old-growth definition or vegetation classification.

\section{Northern spotted owl}

The northern spotted owl was listed as a threatened species in 1990 under the Endangered Species Act of 1973. The owl, which finds suitable habitat in mature and old-growth forests in the region, was listed because of extensive losses of its primary habitat throughout its range resulting from logging, development, and wildfire. The northern spotted owl was central to many of the early debates and controversies over logging of mature and old-growth Douglas-fir and the NWFP ecosystem approach evolved out of single species efforts that focused on the owl.

Effectiveness monitoring of the northern spotted owls consists of monitoring populations in eight demographic study areas within the NWFP area and monitoring spotted owl habitat and dispersal habitat using satellite imagery and inventory plots (Lint et al. 1999). The long-range plan is to reduce the number of relatively expensive demographic monitoring areas and rely more on habitat monitoring to predict population dynamics. These predictive models are the subject of ongoing research. Early results indicate that reliability of these models may not be high enough to reduce or eliminate direct population monitoring.

The northern spotted owl provides a lesson on the value of monitoring some species populations directly, rather than relying only on habitat. Owl populations are declining in the northern part of the NWFP area (Joe Lint, personal communication) and the cause is hypothesized to be competition from the invading, and more aggressive, barred owl (Strix varia), which is spreading into the area from Canada. During this same period, very little cutting of owl habitat occurred on federal lands.

\section{Marbled murrelet}

The marbled murrelet is a small seabird that forages in the near shore environment and nests up to $50 \mathrm{~km}$ inland, in the NWFP area, on large branches or branch fans, which typically occur in large diameter trees. The species was federally listed as Threatened in the NWFP area in 1992 due to population declines that were attributed to loss of mature and oldgrowth forests among other factors.

The effectiveness monitoring for the murrelet consists of at sea population surveys within $8 \mathrm{~km}$ of the shore, and monitoring of nesting habitat based on the vegetation modules described above. Predictive habitat models are under development and may be useful to predict murrelet use as a function of forest conditions. As in the case of the spotted owl, the models are in the research stage.

\section{Aquatic and riparian resources}

The aquatic conservation strategy was intended to conserve and restore processes and habitats that support anadromous fish and other aquatic and riparian dependent organisms (FEMAT 1993). The monitoring approach is based on assessing watershed conditions in 250 randomly selected sixth field watersheds (out of a total of 2600 watersheds) across the NWFP area (Reeves et al. 2004). Watersheds would be sampled on a five-year interval with 50 watersheds sampled each year. Information collected would include in-channel conditions (for example, frequency of pools), vegetation conditions from the IVMP vegetation layer, and road densities and stream crossings from agency road data bases. The aquatic monitoring program intends to develop a series of models that predict in-channel conditions as a function of upslope and riparian attributes. If these models prove adequate they would allow for the expansion of the monitoring effort to wider landscape conditions using the IVMP layers and physical GIS layers. The watershed-scale information is used to assess the condition of a watershed relative to desired conditions that are associated with high-quality habitat for fish species. These desired conditions and watershed quality ratings are developed through an expert opinion process that is codified as a network of relationships in a computer model.

\section{Social and economic benefits}

The NWFP was intended to produce social and economic benefits in addition to the biodiversity goals. This module was developed relatively recently and has not been funded at the level of the other modules. It is intended to determine if predictable amounts of timber and non-timber resources are being produced and to determine if local communities and economies are experiencing positive or negative changes associated with the NWFP. The monitoring is done through collection of data from agency records, community case studies, and the literature.

\section{Lessons Learned}

Many lessons have been learned from implementing this monitoring program. These include:

1. Monitoring species and ecosystems requires real institutional commitments and defined programs with individuals and teams who are accountable for accomplishing monitoring objectives. Too often, monitoring has not been supported with sufficient people and resources.

2. Regional-scale questions require a regional-scale monitoring program. The federal agencies have completed many project and district monitoring efforts in the past but these cannot easily be scaled-up because they lack common questions and measures, randomly assigned samples, and a coordinated data management program.

3. Use vegetation structure and composition as a common denominator. Practicality and cost effectiveness are critical to the success of a monitoring program. It is not practical or scientifically feasible to use a species-by-species approach for hundreds or thousands of species. A coarse filter approach, using vegetation structure and composition as a surrogate for the bulk of species and ecosystem processes, is a good way for management agencies to deal efficiently with many biodiversity issues.

4. Monitor focal species. Some species, such as threatened and endangered species, and other species with special legal or social values are naturally of great interest and are not necessarily covered with vegetative approaches. Such species may require population monitoring to deal with stressors that are not related to habitat characteristics.

5. The scientific understanding of monitoring components varies widely as will the approach to data collection and analysis. Some components such as the northern spotted 
owl have a much more developed scientific basis, more focused questions, and a longer history of ecological study than others. For example, the aquatic and socio-economic components focus on whole systems, which are more difficult to define, and have a much shorter history of scientific research at regional scales. Expert opinion and case studies play more of a role in answering monitoring questions for less-developed subject areas than in studies of the spotted owl and old-forest vegetation.

6. Research is essential to monitoring but research organizations do not have the mandate and resources to implement a large monitoring program. Monitoring typically requires research to help develop and test indicators, models and protocols. Research and management should work together to prioritize research inputs into monitoring programs. In addition, monitoring really needs to be integrated into management and the best way for that to happen is for managers to do the monitoring.

7. Links of monitoring to decision-making (adaptive management) are still being forged. Monitoring is not just data collection for data collection sake - the questions "what information do you need?" and "what are you going to do with it?" are central. Monitoring needs to focus on a set of management-related questions and be linked to decisionmaking. The linkage of monitoring to decision-making has not happened yet. The NWFP, which was intended as a 100 -year plan, is only 10 years old and we have not yet learned how information from monitoring will find its way into decision-making and plan revisions. Many factors influence a policy-maker's decision. The true measure of success is that the decisions of policy-makers will be informed by monitoring.

\section{References}

Cohen, W.B., T.K. Maiersperger, T.A. Spies and D.R. Oetter. 2001. Modelling forest cover attributes as continuous variables in a regional context with Thematic Mapper data. International Journal of Remote Sensing 22: 2279-2310.

FEMAT. 1993. Forest ecosystem management: an ecological, economic, and social assessment Report of the Forest Ecosystem Management Assessment Team, July 1993. U.S. Government Printing Office.

Franklin, J.F., T.A. Spies, R. Van Pelt, A.B. Carey, D.A. Thornburgh, D.R. Berg, D.B. Lindenmayer, M.E. Harmon, W.S. Keeton, D.C. Shaw, K. Bible and J. Chen. 2002. Disturbances and structural development of natural forest ecosystems with silvicultural implications, using Douglas-fir as an example. Forest Ecology and Management 155: 399-423.

Hemstrom, M. A., T. Spies, C. Palmer, R. Kiester, J. Teply, P. McDonald and R. Warbington. 1998. Late-successional and Oldgrowth Forest Effectiveness Monitoring for the Northwest Forest Plan. General Technical Report. PNW-GTR-438. USDA Forest Service, Pacific Northwest Research Station, Portland, Oregon. 37 p. Lint, J., B. Noon, R. Anthony, E. Forsman, M. Raphael, M. Collopy and E. Starkey. 1999. Northern spotted owl effectiveness monitoring plan for the Northwest Forest Plan. General Technical Report, PNWGTR-440. USDA Forest Service, Pacific Northwest Research Station, Portland, Oregon. 43 p.

Mulder, B.S., B.R. Noon, T.A. Spies, M.G. Raphael, C.J. Palmer, A.R. Olsen, G.H. Reeves and H.H. Welsh. 1999. The strategy and design of the effectiveness monitoring program for the Northwest Forest Plan. General Technical Report, PNW-GTR-437. USDA Forest Service, Pacific Northwest Research Station, Portland, Oregon. 138 p. Reeves, G.H., D.B. Hohler, D.P. Larsen, D.E. Busch, K. Kratz, K. Reynolds, K.F. Stein, T. Atzet, P. Hays and M. Tehan. 2004. Effectiveness monitoring for the aquatic and riparian component of the Northwest Forest Plan: conceptual framework and options. General Technical Report, PNW-GTR-577. USDA, Forest Service, Pacific Northwest Research Station. Portland, Oregon. 71 p. 